\title{
BETWEEN LOS ANGELES AND RIO DE JANEIRO: the fight against fascism in a transnational perspective
}

\author{
Wanilton Dudek*
}

\begin{abstract}
The article presents an analysis of the antifascist struggle from the discourses present in the Hollywood Now newspaper of Los Angeles and in the journal Diretrizes do Rio de Janeiro, both of the year 1938. We try to show the positions of antifascist intellectuals of the United States and Brazil by using the press for the dissemination of their ideas and political projects. In this aspect, the article demonstrates that the debates took on a transnational dimension, connecting ideas that circulated at a global level. In Los Angeles, the political action of writers and filmmakers around the Hollywood Anti-Nazi League was important for the intensification of the anti-fascist struggle, while in Rio de Janeiro the positioning of the editors of the magazine Diretrizes expanded the debate on pan- Americanism and the fight against fascism KEYWORDS: Antifascism; Press; Los Angeles; Rio de Janeiro; Transnational.
\end{abstract}

\section{Entre Los angeles e Rio de Janeiro: a luta contra o fascismo em perspectiva transnacional}

RESUMO: O artigo apresenta uma análise da luta antifascista a partir dos discursos presentes no jornal Hollywood Now de Los Angeles, e na revista Diretrizes do Rio de Janeiro, ambas do ano de 1938. Procuramos mostrar os posicionamentos de intelectuais antifascistas dos Estados Unidos e do Brasil ao utilizarem a imprensa para a divulgação de suas ideias e projetos políticos. Nesse aspecto, o artigo demonstra que os debates tomaram dimensão transnacional, conectando ideias que circulavam em âmbito global. Em Los Angeles, a atuação política dos escritores e produtores de filmes em torno da Hollywood Anti-Nazi League foi importante para a intensificação da luta antifascista, enquanto no Rio de Janeiro, o posicionamento dos editores da revista Diretrizes ampliaram o debate sobre o pan-americanismo e o combate ao fascismo

PALAVRAS-CHAVE: Antifascismo; Imprensa; Los Angeles; Rio de Janeiro; Transnacional.

\section{Entre Los angeles y Río de Janeiro: la lucha contra el fascismo en perspectiva transnacional}

RESUMEN: El artículo presenta un análisis de la lucha antifascista a partir de los discursos presentes en el diario Hollywood Now de Los Ángeles, y en la revista Directrices de Río de Janeiro, ambas del año de 1938. Buscamos mostrar los posicionamientos de intelectuales antifascistas de Estados Unidos y del país, Brasil al utilizar la prensa para la divulgación de sus ideas y proyectos políticos. En este aspecto, el artículo demuestra que los debates tomaron dimensión transnacional, conectando ideas que circulaban a nivel global. En Los Ángeles, la actuación política de los escritores y productores de películas en torno a la Anti-Nazi League de la semana fue importante para la intensificación de la lucha antifascista, mientras que en Río de Janeiro, el posicionamiento de los editores de la revista Directrices ampliaron el debate sobre el pan- americanismo y el combate al fascismo

Palabras clave: Antifascismo; Prensa; Los Ángeles; Rio de Janeiro; Transnacional.

\footnotetext{
*The author holds a PhD in History from the University of Passo Fundo, currently has a intership doctoral from the University of Southern California, USA. Contato: Rua Godofredo Grolmann, 862, Bairro São Bernardo, CEP 84600 - 000, União da Vitória, PR, Brasil. E-mail: waniltond@ gmail.com. ORCID: http://orcid.org/0000-0002-8817-0447.
} 
During the 1930s fascism became a global phenomenon, inspiring many political models adopted by governments around the world. The phenomenon of the rise of fascist regimes in Europe happened amid the tragic results of the capitalist world, a direct reflection of the crisis of 1929, and the uncertainties of communism. With the anti-liberal, anti-communist and nationalist discourse, led by the success of Nazism in Germany and fascism in Italy, a large number of supporters of this ideology emerged, as well as movements against it. The anti-fascist struggle was not exclusive to the leftist groups. At various moments there was a convergence between the political movements interested in the fight against fascism, engaged mainly in the groups of intellectuals.

The purpose of this article is to analyze the circulation of ideas of the antifascist movements in the United States and Brazil in the late 1930s from the Hollywood Now pages, newspaper in Los Angeles, and the Diretrizes magazine from Rio de Janeiro. Our sources for research are the early 1938 editions of both periodicals, a period in which debates over the Nazifascist threat intensify with the annexation of Austria by the Reich.

In addition to comparing the two journals, we adopted Transnational History as a methodological perspective. This choice inspires us not only to look for the exchange of materials things and capital between societies, but especially exchanges in the world of ideas. In the argument of American historian Barbara Weinstein, with Transnational History.

The idea is not to change from the cultural sphere to the political sphere; On the contrary, the argument is the impossibility of understanding political developments without a more careful consideration of cultural exchanges, and the role of culture in inter-American projects (whether promoted by the Americans, by Latin Americans, or by those who do not have a point of origin That we can clearly identify). ${ }^{1}$

In this sense, Transnational History has a strong connection with Cultural History, since it is proposed and just and beyond the more traditional methods of Political History when looking at issues involving as global interactions,

Transnational history examines units that spread and filter across national boundaries, units that are ever larger than the nation-state. International models have guided diplomatic history, military history and related fields; the focus of his state is less convincing for non-loyalist historians, which partly explains the embrace of the transnational method by social and cultural historians. ${ }^{2}$

In this aspect, we are interested in observing the exchanges between the societies involved, trying to understand how these networks extrapolate the national spaces, creating a 
global debate, exemplified in the anti-fascist movements of the United States and Brazil. This is a way of problematizing ideas much more than frontiers. ${ }^{3}$

In the Americas, the debate on fascism penetrated all spheres, politics, economics, or culture, and gained strength in so far as the news of the geopolitical intentions of the governments of Adolf Hitler in Germany and Benito Mussolini in Italy arrived more often through the press. The discussions about the meanings of fascism gain diverse interpretations by who are produced and read the contents.

Another contributory factor was the large number of political exiles who looked for refuge in the American continent during the 1930s and 1940s. Politicians, intellectuals, and artists against of fascism were persecuted in their home countries, creating a wave of immigration with the purpose to escape of persecution in the fascist areas of Europe. In the first place, often France, but with a clear possibility of the Nazi advance in that country, the American continent became the main destination of exile in the 1930s and 1940s. Thus, a broad network was formed of antifascist activities in the United States and Latin America with a circulation of magazines, newspapers and other periodicals in which the experiences of the authoritarian governments from Italy and Germany were constantly attacked.

\section{Diretrizes magazine: Pan-Americanism as a weapon against fascism}

For Adrés Bisso, Latin American antifascism was an ideological discourse, attending to specific political interests. According to him it was an appropriation, for local and continental use, of a European discourse. ${ }^{4}$ The Historian Angela Meirelles de Oliveira argues that the antifascist struggle in Brazil was not a complete appropriation of international models but rather a resignification of this struggle, very influenced by the questions about "nationalism" that had been

present since the 1920s. ${ }^{5}$. In this way, the antifascist struggle in Latin America succeeded in adding several social fields and all the ideological diversity that appeared during the first decades of the twentieth century.

In the first years after the Revolution of 1930, the Brazilian president Getúlio Vargas began to put into practice a program of populist government, based on concessions to all social groups that made up Brazil. In the 1934 constitution there were advances in the labor issue, establishing an eight-hour working day, minimum wage, paid vacations and several other rules that made him gain a great political capital with the workers. At the center of their actions was 
the discussion about the country modernization around the nationalist spirit. Education, public security and economic issues have undergone major changes under the influence of the nationalization project. Thereby, institutions like the Armed Forces and the police were important pillars in the maintenance of this proposed political model. The example of this process was the increase in the number of political prisons after 1933, when Filinto Müller became Chief of Police of the Federal District, making the Department of Political and Social Order (DOPS) one of the most important organs for the Vargas government. ${ }^{6}$

This situation worsened in response to the attempt of a Communist uprising in army barracks in 1935. Then came measures that deeply compromised the activities of anti-fascist intellectuals in Brazil, largely centered around the Liberating National Alliance (ANL), with persecution and intensification of the restrictive measures of the State.

The strong repression unleashed by the events reached almost all those involved or sympathizers of the ANL: military, intellectuals, university professors, writers, deputies and even the mayor of the city of Rio de Janeiro, Pedro Ernesto. ${ }^{7}$

The term "intellectual" here is linked to all those who carry out activities in the field of writing and the arts, and thereby have become involved in the political struggles of the period. With this, a significant number of intellectuals have withdrawn from the national public space, either because they fled to neighboring countries, such as Argentina and Uruguay, or because they were arrested on charges of association with communist activities. Therefore, the anti-fascist struggle of this period was marked by sporadic publications in newspapers or other existing journals, without maintaining their own or formal organizations.

Even with the repression and censorship increasingly present after the coup of 1937 , which resulted in the formation of Estado Novo, politically marked anti-fascist publications once again circulated in the Brazilian scene. An example of this is the periodicals Diretrizes, Cultura and Mensário Democrático, both from Rio de Janeiro. The Diretrizes magazazine, object of our study, was founded by Antonio Jose Azevedo Amaral, journalist and supporter of Estado Novo, who invited the journalist, Samuel Weiner, and both began to edit it. Six months after the launch of Diretrizes Azevedo Amaral did not compress with editorial directions and left the magazine.

His team consisted of thought-provoking intellectuals such as Moacyr Werneck de Castro, the then Communist Carlos Lacerda, and other members of the Communist Party. Samuel invited several writers such as Graciliano Ramos, Astrogildo Pereira, Adalgiza Nery, Jorge Amado, Octávio Malta, Rachel de Queiróz among others to form 
the team of his magazine, which was submitted to the previous censorship of the DIP. His goal was to fight against fascism and Nazism. ${ }^{8}$

The main justification for maintaining these publications, even in a political scenery, marked by censorship, were the initiatives of the Brazilian Integralist Action (AIB), a fascist movement, which attempted a coup against the Getúlio Vargas government in 1938. In addition, although economic relations between Brazil and Germany were very intense during the 1930s, there was a strong approximation in the economic and cultural relations between Brazil and the United States. In the first issue of the Diretrizes magazine the international political framework was at the center of the discussions, which would make a strong mark of the other editions. According to Duque Filho "The Diretrizes magazine represented a platform of prominence for Pan-Americanism, encouraging the expansion of commercial, cultural and political relations with the United States." 9

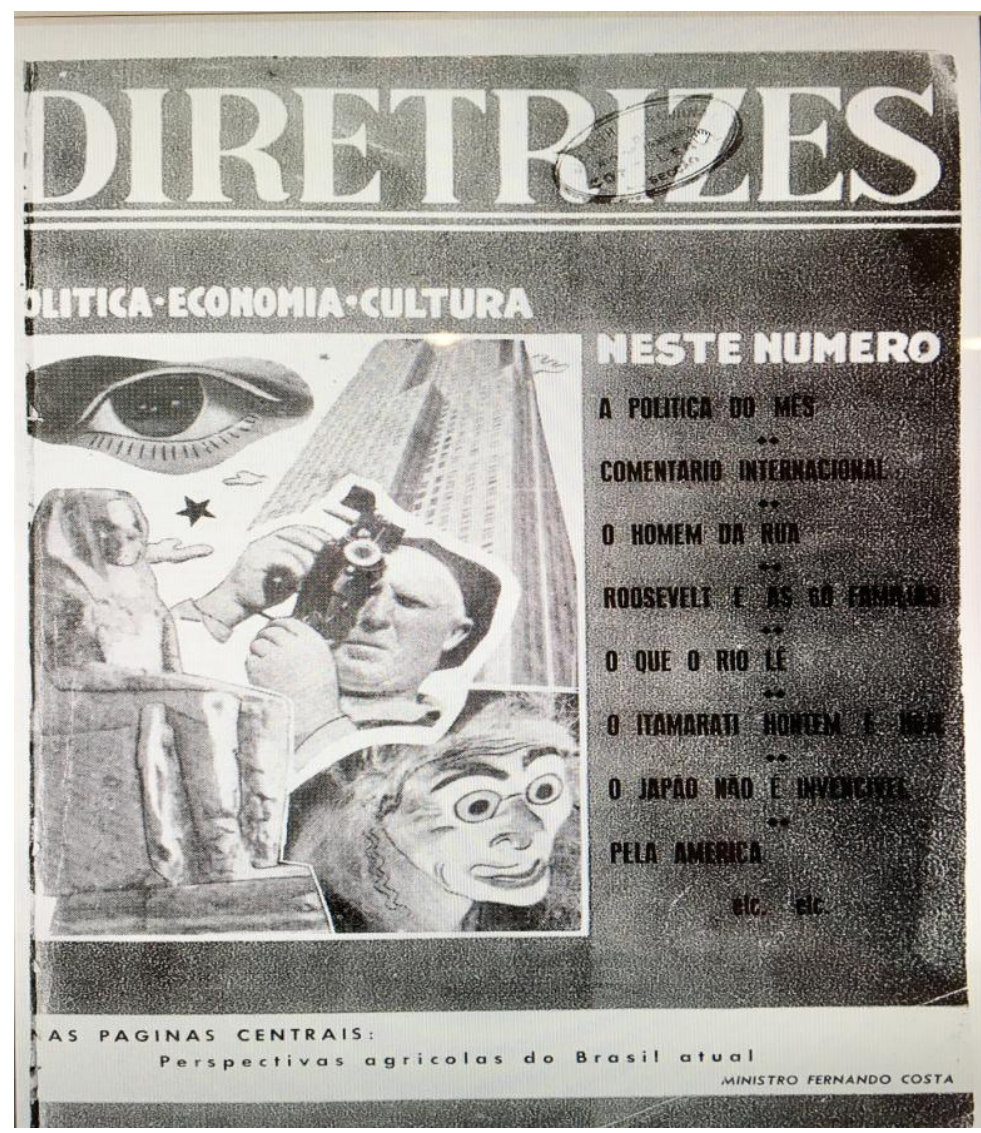

Figura 1:Diretrizes Magazine, April, 1938. National Library, Digital Hemeroteca. 
In the editorial, journalist Azevedo Amaral presented the publication's intentions, openly attacking fascism and Plinio Salgado's attempts at the AIB, citing those who followed him as "social elements that systematically refrain from thinking." Still according to Azevedo Amaral

The failure of this initiative and the more or less simultaneous failure of other formations also inspired by the fascist models that were beginning to be imported into Brazil served to strengthen the general conviction about the impossibility of acclimatizing in our midst currents of this nature. ${ }^{10}$

The articles in the first issue of Diretrizes followed the same line as Azevedo Amaral's critics. There were several collaborators linked to communism, and at the moment there was a consensus in the direction of the Brazilian Communist Party (PCB) that an approach with the Vargas Government was necessary, in order to strengthen the fight against fascism. Rubem Braga maintained a monthly column in the magazine, that although never affiliated to the PCB was married with a communist militant, Zora Seljan. In his article, "The Man on the Street," he dealt ironically with the failed attempt of the Integralist coup:

They wanted the monopoly of patriotism. They also monopolized honor. In the vague hours they also monopolized, God. And when they had nothing to do, they monopolized the family. They were interesting, and amusing. But then they started to get bucks. They wanted to kill everyone. No one wanted to die. The Doctor. Getulio Vargas was very upset. Came the Caraval. On Tuesday, the day of the holidays, the men wanted to play a game. It was not right. Democrats, Phenians, and Devil Lieutenants exist for many years. The last-minute competitor did not get anything. It's natural. We like Carnival like that, once a year. But putting a club in the government was not right. After the Carnival ended, the government thought there was no reason to continue the club. ${ }^{11}$

In the late 1930s there was pressure from the intellectuals and the Brazilian press for the distancing of the Vargas government from Nazi Germany. At the same time, the institutional relations between Brazil and the United States only increased during the period. More articles appeared in the press, praising the policies developed by the government of Franklin Delano Roosevelt, valuing democracy and Pan-Americanism. In this sense, the Diretrizes magazine was one of the spokesmen in favor of the approach with the United States. In the article "The Brazilian chancellor", an analysis and the transcription of a speech given by the Minister of Foreign Affairs, Osvaldo Aranha, on March 2, 1938, in which he praises the United States, was produced, affirming that all Brazilians recognize The greatness of your civilization and the penetrating character of your institutions "12. Azevedo Amaral writes exalting the speech of Osvaldo Aranha, reinforcing the need for rapprochement between Brazil and the United States. 
Brazil, within the limits of its resources and faithful to the postulates of PanAmericanism, for which it has always guided its foreign policy, stands alongside the United States and other nations of America in defending this continent and humanity against harmful action of the retrograde and obscurantist forces, who oppose the establishment of an international juridical order and seek to bring civilization back to warlike barbarism. ${ }^{13}$

This sense of need to combat fascism having as allies the Americans discussed in the public sphere was mirrored by the diplomatic actions of the two countries. At the invitation of President Franklin Delano Roosevelt, in early 1939 a diplomatic mission led by Osvaldo Aranha, which established five agreements between the two countries in the economic sector. The "Aranha Mission", as it became known, also agreed to an exchange of visits between the chiefs of staff of the Brazilian and American armies, in order to prevent the German military plans on the continent.

The evils of fascism could be removed from the American continent through the cooperation of forces between nations. That is why the speech in favor to the United States became so present on the anti-fascist fronts. Thus, the rapprochement with the United States also represented the rapprochement with the modern, with the imaginary of freedom, a concept well developed in American culture. In opposition to this was Europe, the "Old World", where the concept of civilization came into conflict with authoritarian regimes. Corroborating with the thesis that fascism represented a decadence of civilization and culture, Azevedo Amaral describes in his April 1938 editorial in Diretrizes, the performance of fascism as something disconnected from reality: "The psychological process of the conversion of integralism was analogous which leads individuals to imitate attitudes and habits of Hollywood characters movies." 14

The direct relationship between fascism and war has become one of the main weapons of antifascist discourse. In support of this hypothesis was the analysis of the global context of the year 1938 mentioning that the formation of the Rome-Berlin Axis had a warlike purpose and threatened the western democracies. In the Diretrizes article entitled "The Roma-Berlin Axis from the British Imperial Perspective" Azevedo Amaral discusses the problem that the actions of the governments of Italy and Germany bring to the support of the peace. In March 1938 Nazi Germany annexed Austria, completely defying the Treaty of Versailles, in a show of strength for the other European powers. 
According to the text of the Diretrizes, Nazism was also beginning to pose a danger to Brazil. Initiatives to expand the German Empire could target colonies of Germanic immigrants in various parts of the world, including in Brazil.

The tortuous process of interventions to create critical situations in other countries is already being practiced and could very well be analyzed in the preparation of ${ }_{15}$ movements that would serve as a prelude to the organization of Nazi "small homelands".

At the end of the text is reinforced the thesis present throughout the magazine that it was necessary to work in the perspective of "American solidarity" in order to show the Reich and other fascist forces that there would be cohesion between the American nations to prevent the "Pan-Germanism" hit the mainland, as well as a reflection on articles in the German press that made clear the intentions of Nazism's "hostile sentiment against Brazil."

The journalist and leader of anti-Nazi movements in Brazil, Karl Lustig Prean, an Austrian exiled in Brazil between 1937 and 1948, wrote in one of his letters about the alliance between Brazil and the United States during World War II that "Brazil and North America make this war in favor of humanity and civilization, justice and culture". From the beginning of his exile in Brazil, Lustig Prean maintained contacts with the political movements organized by exiles in the United States, being part of the Anti-Nazi German group that added the magazine Freie Deutschland in Mexico. Thus, the circulation of anti-fascist ideas in America accompanied the principle of protecting the continent against the invasion of a political model that represented a degrading mode of civilization.

\section{Hollywood Now and an Anti-Nazi League in Los Angeles}

The United States underwent profound transformations in the 1930s, most notably with the start of the Franklin Delano Roosevelt administration in 1933. From New Deal, the largescale banking reliance began to recover from the great crisis of 1929 , unemployment began to Decrease Significantly, as well as some laws that have improved as conditions of ongoing work in force in the period. Unlike its predecessors, Roosevelt left the big stick policy and adopted a "good neighbor policy" with the countries of Central and South America. In relation to Europe, the United States, they tried to stay away from the conflicts of the continent as much as possible. However, the period was also marked by the formation of state surveillance agencies, mainly as 
cultural, political and cultural manifestations of the North American population. According to historian Alexander Stephan

In this period as Franklin Delano Roosevelt's "great police government" and his desire to centralize mega agencies The FBI formation with an ideological influence of its director, John Edgar Hoover, based on xenophobia and anticommunism. ${ }^{16}$

Hoover had extensive experience in the Department of Justice during World War I, when he was responsible for monitoring how foreign activities in the United States, especially the Germans. From the outset, Hoover assumed the role of "citizen protector" against foreign threats, with a strong anti-communist and anti-fascist discourse.

The acceptance of the president was very large among a population. Roosevelt was reelected in 1936, with a greater advantage in the history of the American elections until then. The transformations in the social spectrum were interpreted by several writers of the time. John Steinbeck wrote about the changes in the rural and industrial world in "The Grapes So Wrath," published in 1939, followed shortly by "For Whom the Bell Tolls," on the Spanish Civil War, published in 1940. Artists and intellectuals talked about the social changes, and on how an art and how words passwords become weapons to contribute to progress. In this context, German antiNazi writers in the United States began to share with American writers as similar views on how social transformations the world went through.

The Hollywood film industry acted in the creation of this imaginary about America, interpreting and analyzing the social transformations of the period. Productions such as John Ford's "The Grapes of Wrath" (1939), or the satire in Charles Chaplin's "Modern Times" (1936), interpreted more critically the unbridled advance of modernity. However, some of these productions began to be criticized by conservative groups of politicians and religious, so several of these works were censored. On the other hand, most Hollywood films have become instruments that served to further fuel a more positive view of American progress. Historian Leandro Karnal argues that Hollywood did much to foster the imagery of "ideal America," with its productions that emphasized this vision of the country. "The Hollywood fantasy world cultivated belief in the possibilities for individual success, in the government's ability to protect citizens against crime, and in a vision of America as a classless society"17

In the United States antifascism has become part of the national agenda in combating subversive activities. The idea of "Free America" contrasted with any possibility of advancing the 
models inspired by Mussolini's Italy or Adolf Hitler's Germany. In this respect, the anti-fascist struggle was concentrated mainly in the fight against Nazism, with the intense participation of the German-speaking exiles in Southern California.

In 1936 a group of people involved with the Los Angeles film industry created the Hollywood Anti-Nazi League (HANL). Most members were film directors and producers in Hollywood, some Americans such as Dorothy Parker, Alan Campbell, Dashiell Hammett, John Howard Lawson, Phillip Dunne, and others, political exiles pursued by the Nazi regime who had Established in California, as the writers Ernst Lubitsch and Otto Katz. At various times HANL was accused of being a communist organization whose purpose was to expand the activities of the Communist Party in the United States. However, in addition to the affiliations or political preferences of its members - there were Communists, Liberals, Jews, Social Democrats and several other political tendencies involved, but in common anti-Nazism - the movement sought to act through artistic and intellectual production, resulting in the production of films such as Blockade (1938), with a strong critical appeal to the Spanish Civil War, banned in fascist countries Italy, Germany and Spain, and also through periodicals, such as the Hollywood Now newspaper, which is the subject of our analysis.

The Hollywood Now newspaper was a weekly publication of HANL, with writers and film producers Donald Ogden Stewart, Marian Spitzer, and Alan Campbell as editors. The whole editorial was aimed at attacking fascism and Nazism, defending the democracy. The newspaper did not have a long life, lasted from 1937 until 1940, but always maintained the same position in the period in which it was published. In all its editions the phrase "The newspaper in Defense of American Democracy" was written just below the name on the cover of the newspaper. The connection with the film industry was also evidenced on the front pages, where a drawing with a movie camera was enclosed in a circle at the top left of them. Cultural activities and antifascist political struggle were mixed in the news, as in a story in the April 9, 1938 issue, whose title "Stars meet the anti-Nazi writer" describes the meeting of actors and actresses with the Writer Thomas Mann at a Hollywood film awards event. 


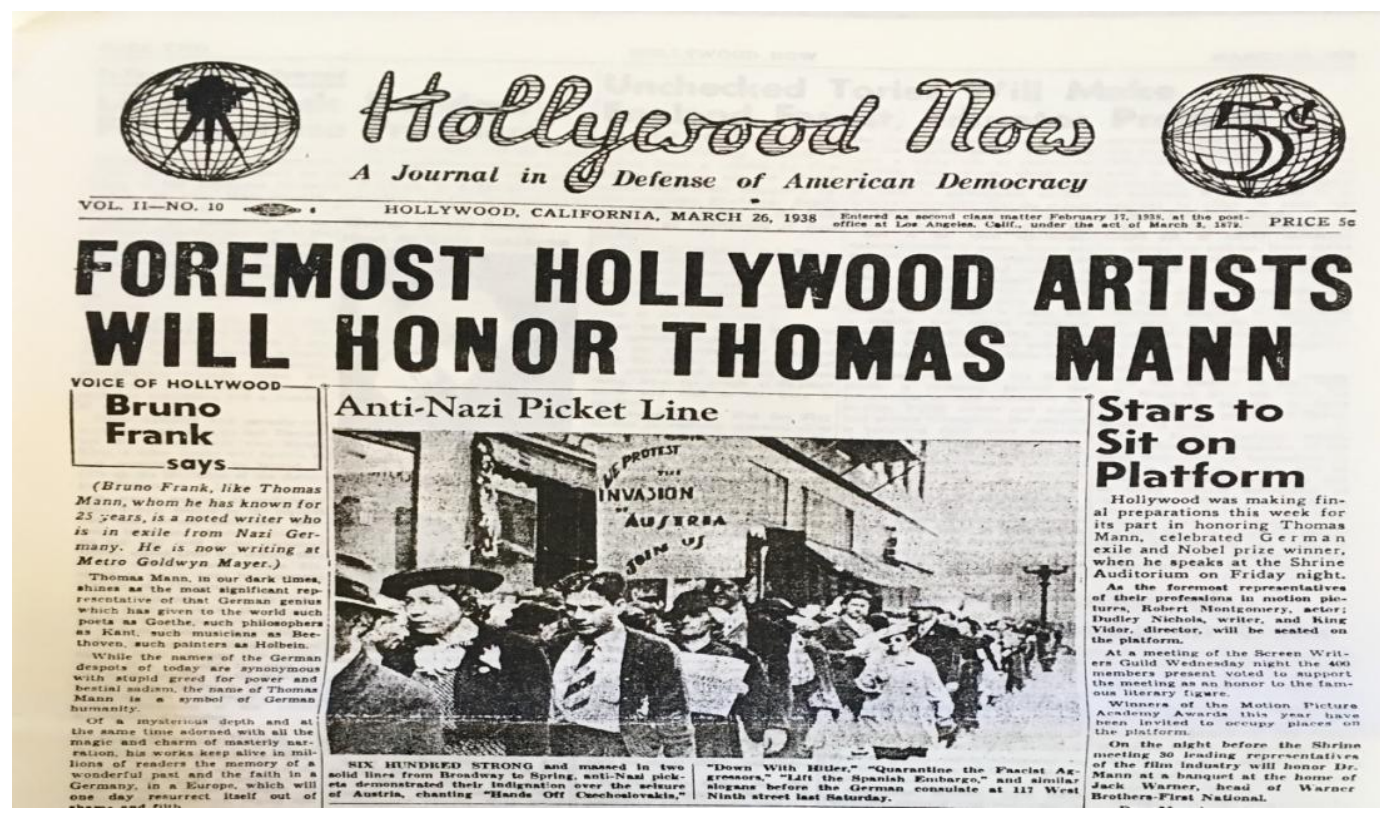

Figura 2: Hollywood Now, March 26, 1938. University of Southern California, Special Collections. Harold Von Hofe papers. Box 10.

In the Hollywood Now edition of March 26, 1938, two events guided the entire discursive construction of the editorial and much of the story of the HANL journal: the annexation of Austria by Nazi Germany and the coming of writer Thomas Mann to the United States. These two facts served as the discursive platform of the anti-Nazi message present in the stories. The front page prints a picture of the demonstrations in Los Angeles on March 25 against the annexation of Austria and other measures of the German government, directly attacking the figure of Adolf Hitler. Demonstrators marched in front of the German consulate where they took signs saying "Down with Hitler" and "Quarantine the fascist agressors." The cover story featured writer and Nobel laureate Thomas Mann, who would come to the Shrine auditorium to give a talk at the event titled "The Coming Victory of Democracy."

In addition to the news, the Holllywood Now editorial was a call from the Los Angeles intellectual community to attend events hosted by HANL. Thomas Mann did not integrate HANL, but his contribution, as in many other anti-Nazi movements during his exile in the United States, was always remembered, especially for the prestige he maintained in America. This is clear in the writing of the matter when mentioning it:

Dr. Mann's subject at the Shrine Auditorium will be "The Coming Victory of Democracy," in which he will express his deep belief in the enduring qualities of the 

League is assisting the Modern Frum in preparations for the lecture. ${ }^{18}$

In the 1930s, the city of Los Angeles, mainly for the activities of the Hollywood film industry, was famous for the reputation of pioneering progressive politics and strong involvement in the fight against fascism in Europe. The American historian Ehrhard Bahr argues that this was one of the main attractions for the coming of political exiles to the region. ${ }^{19}$

This cultural effervescence, of the arts and the global political debate surrounding the fascist threats in Europe, made more and more intellectuals involved in the political struggle. Also in the March 26, 1938 issue of the Hollywood Now newspaper, contributor Alexsander Fielding talks about this politicization of intellectuals, exemplifying Thomas Mann's case. In the article entitled "Great artist turns to politics in writings on Germany and loyalist Spain," the trajectory that led the writer into exile for contesting Nazi laws is described as "a struggle for Christianity, Western morality and civilization", followed by a long debate on the anti-fascist demonstrations of Thomas Mann through writing. This was the trajectory of many German writers during the exile, involved primarily with literature and the film industry also began to compose movements with political activism in the Hollywood scene.

The German writer Bruno Frank, who arrived in the United States in 1937 as a political exile, wrote in Hollywood Now referring to the welcome they received in America and the important presence of Thomas Mann to contribute to the anti-fascist struggle. "America is today the refuge of all modern culture. Here it will survive its years of gloom. The American public, in tending such an overwhelming reception to this great and corageous German, renders to itself the very highest honor." ${ }^{20}$ In this Bruno Frank's speech is also exposed an appeal of gratitude and even same union between the Germans in exile with the Americans. The HANL was a reflection of this, for it was basically formed by these two subjects, both in the anti-fascist struggle.

In the April 9, 1938 issue, the Hollywood Now pages featured an upbeat and highly successful speech at the event where Thomas Mann gave his talk at the Shrine auditorium. Pictures of filmmakers, as if participating in the anti-fascist movement, and a few articles mocking Austria's subservience to Adolf Hitler created the anti-Nazi theme for newspaper. In addition, there were endnotes celebrating the various donations received for HANL, without naming the donors, corroborating the thesis that the anti-fascist activities in Los Angeles were exercised by a large and heterogeneous group. The involvement of various sectors of Los 
Angeles society with HANL advocates and published in the weekly Hollywood Now newspaper marked the beginning of anti-Fascist and Nazi movements in Southern California. It is also important to remember that the Shrine auditorium, where most of HANL's private and public events took place, as the very foundation of the group, belongs to an organization of Masonic orders, in which several of the artists, writers and intellectuals involved were members.

\section{Final considerations}

The anti-fascist struggle was much broader than the publication of newspapers and magazines in order to expose and spread ideas. In this sense, we can not disentangle the role of the struggle of intellectuals from a broader context, involving diplomacy, political parties, government decisions and various other aspects of national and international aspects. It is difficult to evaluate the real influence of the two journals studied in the formation of public opinions in relation to the struggles that were proposed. However, it is notorious that this movement of which the editorials of Hollywood Now and Diretrizes magaznine shared, antifascism, grew very much in the late 1930s, mainly with the worsening of the international context with the beginning of World War II.

The circulation of these ideas has transcended boundaries, without necessarily going through state issues. The mention of the anti-fascist struggles in the United States became a recurrent discursive element in Latin America, reinforcing in many moments the idea that the country was the safe place where "modernity and democracy rested". Even among the foreign collaborators of the Hollywood Now newspaper, this ideal of "free America" was present, exalting the culture of freedom they experienced in the "New World." Corroborating this, the Pan-American ideas advocated in the Diretrizes magazine advocated the alliance between Brazil And the United States, not only in the political arena but also in cultural issues.

The press was the instrument of diffusion of the antifascist ideas, exemplifying how it represents an important form of amplification of political ideas that realize interventions in the reality. In this sense, the brief analysis of two periodicals from different countries in the year 1938 reinforces the premise that the exchange of ideas generates the strengthening of these movements in the national contexts and also contributes to the increase of the capacity of international mobilization. 


\section{Notas:}

1 WEINSTEIN, Barbara. Thinking about history outside the nation: the historiography of Latin America and the transnational bias. Electronic Journal of ANPHLAC. São Paulo, issue 14, p. 9-36, 2013.p.17.

2 SEIGEL, Micol. Beyond Compare: comparative method after Transnational turns. Radical History Review. New York, issue 91, 62-90. 2005. p. 63.

${ }^{3}$ FUNES, Patricia. Save the Nation. Intellectuals, culture and politics in the Latin American twenties. Buenos Aires: Prometeo Libros, 2006. p.14.

${ }^{4}$ BISSO, Andrés. The Argentine antifascism. Buenos Aires: CeDinCi, 2007. p.22.

${ }^{5}$ OLIVEIRA, Ângela Meirelles de. Words like bullets: press and anti-fascist intellectuals in the Conesul countries (1933-1939). São Paulo: USP. Doctoral thesis. 2013. p.16.

${ }^{6}$ CANCELLI, Elizabeth. Between prerogatives and rules: Criminal Justice and Political Control in the Vargas Regime (1930-1945). Cadernos do Tempo Presente, n.15, Mar / Abr., P. 02-35, 2014. p.05.

${ }^{7}$ OLIVEIRA, Ângela Meirelles de. Words like bullets: press and anti-fascist intellectuals in the Conesul countries (1933-1939). São Paulo: USP. Doctoral thesis. 2013. p.16. p. 62.

8 ROUCHOU, Joelle. Diretrizes: a space of resistance in the Estado Novo (1938-1944). Http://www.casaruibarbosa.gov.br/arquivos/file/bolsistas15/FCRB_Diretrizes_um_espaco_de_resistencia.pdf.

Accessed on June 10, 2017. p.4.

9 DUQUE FILHO, 2007, quoted of OLIVEIRA, Ângela Meirelles de. Words like bullets: press and anti-fascist intellectuals in the Conesul countries (1933-1939). São Paulo: USP. Doctoral thesis. 2013. p. 113

${ }^{10}$ AMARAL, Azevedo. Diretrizes: politics, economics and culture. April 1938. National Library Foundation. Digital Library. Rio de Janeiro, Brasil. p. 04.

11 BRAGA, Rubem. Diretrizes: politics, economics and culture. April 1938. National Library Foundation. Digital Library. Rio de Janeiro, Brasil. p. 04. p.11.

12 ARANHA, Osvaldo. Diretrizes: politics, economics and culture. April 1938. National Library Foundation. Digital Library. Rio de Janeiro, Brasil.

${ }^{13}$ AMARAL, Azevedo. Diretrizes: politics, economics and culture. April 1938. National Library Foundation. Digital Library. Rio de Janeiro, Brasil p.12.

${ }^{14}$ AMARAL, Azevedo. Diretrizes: politics, economics and culture. April 1938. National Library Foundation. Digital Library. Rio de Janeiro, Brasil p. 04.

15 AMARAL, Azevedo. Diretrizes: politics, economics and culture. April 1938. National Library Foundation. Digital Library. Rio de Janeiro, Brasil. p.20.

16 STEPHAN, Alexander. Communazis: FBI Surveillance of German Emigré Writers. New Haven: Yale University, 2000. p.11.

17 KARNAL, Leandro. The History of the USA: from the beginnings to the 21st century. São Paulo: Contexto, 2007. p.37.

18 Hollywood Now, March 26, 1938. University of Southern California, Special Collections. Harold Von Hofe papers. Box 10.

${ }^{19}$ BAHR, Ehrhard. Weimar on the Pacific: German exile culture in Los Angeles and the crisis of modernism. Los Angeles: UCLA, 2007.p.85.

${ }^{20}$ Hollywood Now, March 26, 1938. University of Southern California, Special Collections. Harold Von Hofe papers. Box 10.

\section{Bibliographic References}

BAHR, Ehrhard. Weimar on the Pacific: German exile culture in Los Angeles and the crisis of modernism. Los Angeles: UCLA, 2007.

BISSO, Andrés. The Argentine antifascism. Buenos Aires: CeDinCi, 2007. 
CANCELLI, Elizabeth. Between prerogatives and rules: Criminal Justice and Political Control in the Vargas Regime (1930-1945). Cadernos do Tempo Presente, n.15, Mar / Abr., P. 02-35, 2014. FUNES, Patricia. Save the Nation. Intellectuals, culture and politics in the Latin American twenties. Buenos Aires: Prometeo Libros, 2006.

KARNAL, Leandro. The History of the USA: from the beginnings to the 21st century. São Paulo: Contexto, 2007.

OLIVEIRA, Ângela Meirelles de. Words like bullets: press and anti-fascist intellectuals in the Conesul countries (1933-1939). São Paulo: USP. Doctoral thesis. 2013.

ROUCHOU, Joelle. Diretrizes: a space of resistance in the Estado Novo (1938-1944). Http://www.casaruibarbosa.gov.br/arquivos/file/bolsistas15/FCRB_Diretrizes_um_espaco_de_re sistencia.pdf. Accessed on June 10, 2017.

SEIGEL, Micol. Beyond Compare: comparative method after Transnational turns. Radical History Review. New York, issue 91, 62-90. 2005.

STEPHAN, Alexander. Communazis: FBI Surveillance of German Emigré Writers. New Haven: Yale University, 2000.

WEINSTEIN, Barbara. Thinking about history outside the nation: the historiography of Latin America and the transnational bias. Electronic Journal of ANPHLAC. São Paulo, issue 14, p. 936, 2013.

\section{Sources:}

Diretrizes: politics, economics and culture. April 1938. National Library Foundation. Digital Library. Rio de Janeiro, Brasil.

Harold Von Hofe: personal papers. Hollywood Now newspaper. March 28, 1938. Special Collections. Box 10.. University of Southern California, Los Angeles, California, United States. 